JPPUMA: JurnallmuPemerintahan dan Sosial PolitikUMAUournal of Governance and Political Social

UMA), (9)(2)(2021):173-183, DOI: 10.31289/ippuma.v9i2.5095

JPPUMA: JurnalIlmuPemerintahan dan Sosial Politik UMA

(Journal of Governance and Political Social UMA)

Available online http://ojs.umaacid/indexphp/ippuma

\title{
The Application of Innovative Technology on Internal Border Control in Schengen Area
}

\author{
Septyanto Galan Prakoso1)*, Eryan Dwiki Effendi'2), Rizaldi Yazid Purnama \\ Putra $^{2)}$, Rameez Ali Surya Negara2), \& Niki Wahyu Sayekti2)* \\ 1) Institute of Political Science, National Sun Yat-sen University, Taiwan \\ Department of International Relations, Faculty of Social Science and Politics, \\ Universitas Sebelas Maret, Indonesia \\ 2) Department of International Relations, Faculty of Social Science and Politics, Universitas \\ Sebelas Maret, Indonesia
}

Received: April 14, 2021; Reviewed: June 28, 2021; Accepted: July 25, 2021

\begin{abstract}
This article or writing aims to discuss the application of technology and certain mechanism as the impact of a disruptive era on internal border control in the Schengen area. The problem is focused on the inner border system, which got reintroduced as a countermeasure against the 2015 Migrant Crisis in Europe. The analysis conducted in this research will measure whether the application of technology gives a practical benefit in alleviating internal border controls or negative impacts such as discrimination towards refugees and immigrants in the Schengen area. To approach this problem, a theoretical reference is used from international relations' perspective, as a part of the political science greater scope on the issue. The data is collected through library research and analyzed qualitatively. This study concludes that made various improvements and improvisation in the implementation of border controls. There are several steps taken by the EU for border control checks by utilizing technology such as Visa Information System (VIS), Schengen Information System (SIS), European Travel Information and Authorization System (ETIAS), and FRONTEX. These technologies allow Schengen states to share visa data about individuals who enter the European Union from its various borders and enable seamless cooperation regarding border controls and law enforcement and visitor tracking between countries. This study concludes that innovative technology on internal border control in the Schengen Area is well applied and projectively very useful to tackle the security concerns and conflicting interests within the Schengen area and remove the needs of unnecessarily long physical internal border controls.
\end{abstract}

Keywords: Schengen Area; European Union; Application of technology; Disruptive Era; Migration.

How to Cite: Prakoso, S.G., Effendi, E.D., Purnama, R.Y., Negara, R.A.S., \& Sayekti, N.W.. (2021). The Application of Innovative Technology on Internal Border Control in Schengen Area. JPPUMA: Jurnal IlmuPemerintahan dan Sosial Politik UMA (Journal of Governance and Political Social UMA), 9 (2): 173183

${ }^{*}$ Corresponding author:

ISSN 2549-1660 (Print)

E-mail: septyantogalan@gmail.com

ISSN 2550-1305 (Online) 


\section{INTRODUCTION}

Schengen Agreement, named after a small town in Luxembourg, is made by five states members of the European Economic Community. These countries are Belgium, France, Luxembourg, the Netherlands, and West Germany. Signed The Agreement on June 14, 1985, proposed the idea to decrease gradually and finally abolish border checks at the member states' common borders. The Schengen Convention then supplemented this Agreement, which offered a complete removal of centralized and systematic internal border controls and a shared visa policy ( European Council, n.d.).This Agreement gave birth to the Schengen Area or Schengen Zone, in which the people of all member states could move freely between countries without any hindrance. The Agreement was then incorporated into the European Union law, making sure that most members of the European Union would have to recognize or even join the Schengen Area.

Schengen Area is a significant milestone in the integration process of the European Union. The free movement of people within the Schengen Area stimulates the economy within the member states. Furthermore, the citizens of the European Union benefit from reduced travel time, removal of barriers to moving in and out of borders, and job flexibility. The freedom of travel and movement has become a norm. Many have voiced their concern over the reintroduction of internal border checks within the Area stating that it would disrupt and challenge the Schengen Area (The Economist, 2018). However, the reintroduction of internal border checks was merely a reaction to the European Union's dire problem, The 2015 Migrant Crisis.
The conflict in Syria mainly caused the 2015 Migrant Crisis. This CrisisCrisis, in turn, pushed a few European countries such as Germany, France, Sweden, Denmark, and Austria to reintroduce internal border controls to screen and prevent undesirable individuals from entering their borders. Some of those countries cited the rise of terrorism and secondary movements. ${ }^{1}$ Their reason to reintroduce internal border controls (European Parliament, 2017) would be perfectly acceptable in a normal situation. However, reintroducing internal border controls challenges the Schengen Agreement. It compromises the Schengen Area - 26 European states that have officially abolished all types of border control and passport checks at each other member's border.

Reintroduction of internal border controls within the Schengen Area is acceptable and legal. A country within the Schengen Area may reintroduce internal border controls if necessary. However, the period of the reintroduction must not exceed six months. A government could extend or lengthen the reintroduction further, but an extension can only justify an extreme case of importance. Such as if the border controls are not developed, it could threaten the overall function of the Area. As stipulated in Article 29 of the Schengen Borders Code, The maximum extension of the reintroduction is two years (EUR-Lex, 2019). In 2019, four years after the migrant CrisisCrisis, border controls have become the norm for a few member countries of the Schengen Area. France, for example, reintroduced border controls in 2015, after the Paris terrorist attack, and since then, the rules are still in place and with no clear prospect that they would lift it anytime soon (Scatch, 2019). Four other countries had done the same; they had reintroduced

\footnotetext{
${ }^{1}$ Secondary movements occur when refugees or asylumseekers move from where they first arrived to seek protection or permanent resettlement elsewhere.
} 
border controls when the migrant CrisisCrisis began and continued until 2019(Scatch, 2019). The European Parliament condemned the authorities in May 2018 (European Parliament, 2018). Four years of internal border controls are well beyond the legal limit and could threaten the Schengen Agreement by normalizing internal border controls within the Area. (Etzold \& Bossong, 2018) In addition to that, the European Migrant crisis has surfaced another major problem within the European Union, mainly the people's distrust and dissatisfaction towards the supranational organization that has fuelled the rise of anti-Euro parties and their influence in Europe.

There are several pieces of literature used as the base of analysis of this research. Some are more relevant and vital than others. One of them is an article written by Julian Kamasa, entitled "New Technologies for Border Controls in Europe". This article was published in CSS Analyses in Security Policy No. 255, December 2019. In the article, Kamasa explains the importance and the applications of the new technologies in several border points of Europe. Kamasa discussed how new technologies could benefit border controls in Europe, especially when facing threats such as illegal migration and crimes. These are considered as challenges, complimenting the very source of the problem in the modern world, which is the increasing mobility of people. However, Kamasa was aware of the implementation process, which definitely will not be easy. However, the article shows that technology innovation and its application are inevitable to comply with adequate border controls. The second article is written by Ben Hayes, entitled "Statewatch Analysis: From Schengen Information to SIS II and the Visa Information System (VIS): the proposals explained," published by Statewatch Report in 2004. Hayes discussed the expansion of SIS and its conception as compensation for the removal of physical internal borders within the Schengen area. This article gives us insight into how SIS works, especially the newer SIS II that includes biometrics and new categories such as terrorist suspects. This newly expanded system is even more necessary in recent times post-Migrant CrisisCrisis. Hayes also discussed the negative social impact that may be caused by this new system, especially on how Muslims, Arabs, migrants, and refugees would bear the brunt of the negative impact.

Another article is written by Magdalena Konig, entitled "The Borders, They Are a Changing! The Emergence of Socio-Digital Borders in the EU", published in Internet Policy Review, Journal of Internet Regulation, Vol. 5, No. 1. Konig discussed the transformation of the border in the EU and how the authorities should react to it. In current times, digitalization should also be applied to improve the quality of the wall in facing the influx of migrants who can become potential problems. More importantly, it should spread the awareness of digital-infused borders more so that the EU can ensure the region's stability in the sector of migration and population control.

The three articles mentioned above talk about the importance of new technologies, how they are applied, and their social ramifications. However, neither articles discuss detailed political discussion within the Schengen Area that led to the application of the aforementioned new technologies. Building on that premise, this research aims to focus the conversation on the Schengen Area and the latest technologies that have been implemented in regards to border control.

This research is conducted to portray the application of innovative technology in a border control mechanism, which takes place in European Union, with the Schengen area regime also occurring. Whether or not the European Union will benefit from the application to overcome and prevent 
migrant crises in the future will be discussed in this research.

\section{RESEARCH METHODS}

This research used the descriptivequalitative method with a literature study as the main sources to make the analysis. Chose The descriptive research method since this writing aims to describe a phenomenon that, in this case, is the application of innovative technology on internal border control in the Schengen Area as a response to the Migrant Crisis in Europe. Using the said method, it will be described or elaborated in this paper how the possible threat to social and national security caused by the migrant CrisisCrisis has shaped or affected the European community, especially countries in the Schengen Area. Due to the huge influx of refugees, member countries were challenged with difficult decisions over internal border controls that would affect the Schengen's Area's function and existence. Hence, the idea of innovative technology application arises in response to that concern.

Using data collected through various digital sources, later analyzed this issue deeply with a qualitative approach. Official statements/publications, credible news reports, and experts' opinions were gathered and extracted from various official online documents and websites to support the analysis made in this paper. This detailed data, collected from multiple online sources, stands as the majority of the data used in this research. Exploited The acquired data to examine further and elaborate on the discussed matter. The literature review is also presented as a reference and comparison to the issue highlighted in this research.

\section{RESULTS AND DISCUSSION}

In 2015, Angela Merkel stated that she would open Germany to accept all refugees.
The statement has given Merkel the title "Mama Merkel" from migrants (Ensor, 2016). By delivering such a statement regarding refugees and migrants, Germany put tremendous pressure on other countries that did not agree to accept refugees, such as Hungary, Slovakia, and the Czech Republic, to follow suit. The stance delivered by Mama Merkel, who is regarded as the leader of the EU by political analysts, met a lot of criticisms, both from other EU member countries and from German politicians as well. The leaders of Hungary, Slovakia, and the Czech Republic expressed their disagreement towards the policies regarding migrants issued by Germany. They considered the inconsistency of German policy to be the main enemy of the EU (The Guardian, 2015). German policy divides the EU into two factions, those who are in support and against. With this policy, some countries have realized the importance of helping human beings on humanitarian grounds, whereas other countries started to tighten their border control. United Kingdom's policy of rejecting all types of refugees is still maintained and not following Germany's footsteps to open up (Lichfield, 2015). However, the German decision influenced the British Refugee Council to immediately urge the United Kingdom's government to follow Germany's migrants' policy. The resistance towards Germany's policy from within Germany comes from Bavaria, which has cast objections regarding the policy to accommodate all refugees who come to Germany without any definite limits on their number (Anne, 2016). The external party that strongly condemns Germany is Hungary. Hungarian Prime Minister Viktor Orban blamed Germany for the overflowing of refugees who came to EU countries (Deustche Welle, 2019). Orban regretted that Germany's policy would be a problem for European Union's external border countries. The Czech Republic, a transit country for refugees before turning to Germany, also had a hard time 
accommodating refugees who wanted to continue their trip to Germany. Both Hungary and the Czech Republic are suffering the secondary movement of refugees, in which both countries are used as a stepping stone or a necessary transit to gain entry into Germany, the main destination of migrants. The huge influx of refugees has indisputably created complexity in the host countries even if said countries only act as transits such as Hungary and the Czech Republic.

Austria has also implemented a new policy that allows its immigration office only to accept 80 refugees to enter each day and a quota of 3,200 migrants to travel through Austria to get to Germany (BBC, 2016). Croatia, one of the gateways into the European Union, is also experiencing difficulties dealing with the migrant problem due to its overwhelming influx. In 2015 the Croatian government said that the country was overflowing with migrants and would not accommodate more (CBC Radio, 2015). Based on the latest reports, migrants are still attempting to cross Croatia to enter the European Union (Vladisavljevic, 2019). Austria and Croatia are only a few examples of countries that felt the effects or impacts of the Migrant Crisis in 2015. In the end, Austria and Croatia decided to close their borders with other countries to lessen the crisis' impact on their lands.

The European Union established Frontex, or the European Border and Coast Agency, in 2004, headquartered in Warsaw, Poland. This institution employed 300 individual officers in 2014 to operate. Frontex is responsible for external border control assignments and the reinforcements of European Union Borders (Schumacher, 2018). The aftermath of the 2015 Migrant Crisis expanded Frontex's responsibility to tighten the supervision of refugees who want to cross into the EU. Along with the addition of the new responsibility given by the Council of the European Union, would reinforce Frontex with 10,000 border guards, a stronger mandate of returns and closer cooperation with non-EU countries, including those outside the EU's immediate neighborhood, will also be possible (European Commission, 2019). Strong political support from the EU is crucial, but it is also worth noting that it would take some time to increase officials to reach its maximum potential.

Recently, Frontex faced criticism regarding migrant abuse. German public broadcaster ARD and The Guardian have accused Frontex of using violent measures and mistreatment of migrants at the European Union's border, specifically in Hungary, Bulgaria, and Greece (DW, 2019). For the time being, Frontex denied the accusations, claiming that there were no complaints filed against Frontex's border guards and that the agency would take immediate action should any reports be made (The Japan Times, 2019). Increasing Frontex's capacity to tackle the migrant challenge is the right move made by the Council of the European Union. However, Frontex should be closely supervised to reduce any risks of the humanitarian issue in the future.

As shown by Figure 1, about the election results in 20 European Countries in the late 1990s, as published in the New York Times (Aisch \& Pearce, 2016), the "right-wing Parties" are gaining considerable social support across the European Union. Why is this matter important to be understood? Simply because the initiation to limit (or even greatly reduce) the flow of immigrants into the European Union often become the objectives of these right-wing political parties spread across the member countries of the European Union. As can be seen in the tables below, is the intensity of how right-wing view controls the government or dominate the politics in several European Union member countries:

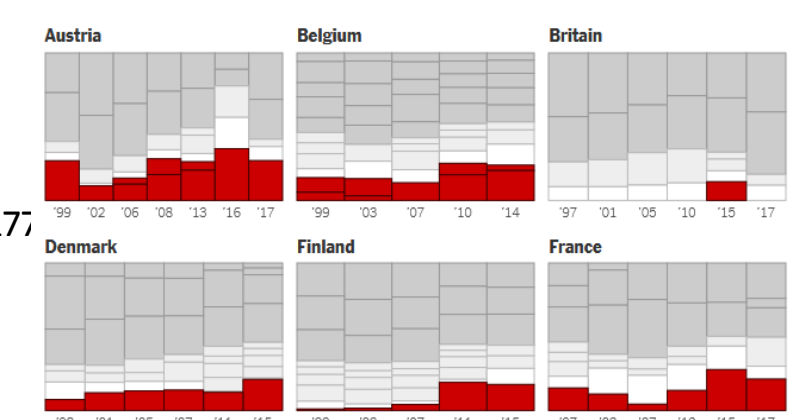




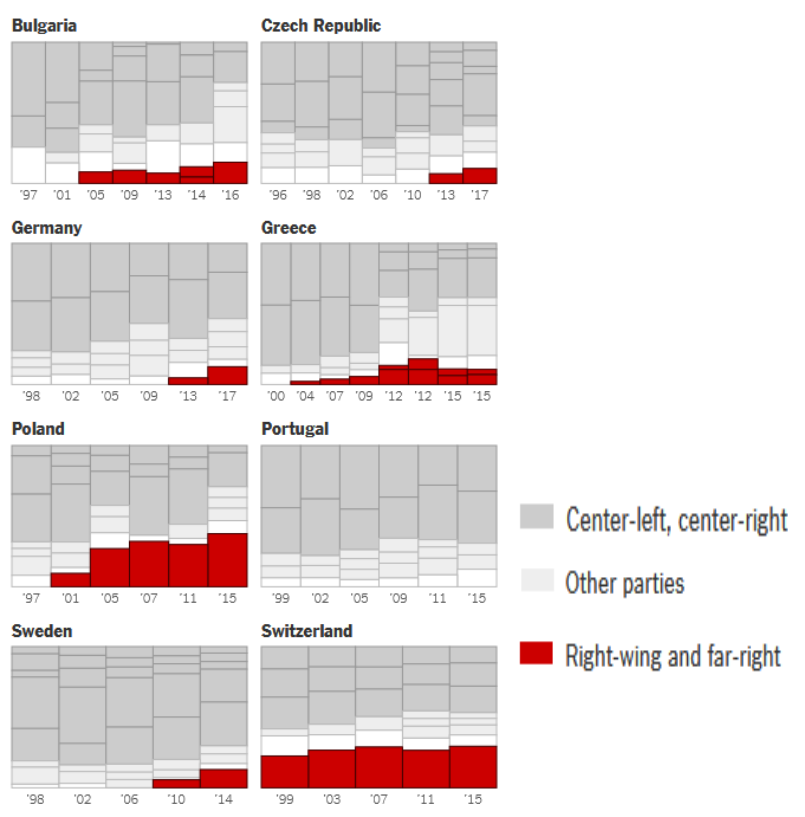

Figure 1. Party Ideology in Parliamentary Election

As the red bar represent a right-wing and far-right ideology, we can see that these red-wing parties in some countries are constantly holding their view in Parliament; some are even sustainable throughout years like in Hungary, Poland, and Austria. These parties carry a very strong opinion towards an issue that a country is currently facing. In this case, most of these parties voiced strong disagreements and objections towards accepting migrants and the European Union's policy regarding migrants. The Christian Democratic People's Party
(KDNP) in Hungary, in particular, has voiced its rejection of migrants entering Hungary. KDNP holds significant power in the Hungarian Parliament, and thus their view regarding migrants carries weight and could influence Hungary's national policy. In Poland, the Prawoi Sprawiedliwość (PIS) has declared themself as Eurosceptic. PIS rejected the quota system proposed by the European Commission regarding migrants, citing that the migrant issue is strongly intertwined with national security in which the PIS is very concerned (Euractiv, 2017).

Another notable country with a strong right-wing influence within its Parliament is Austria. Freiheitliche Partei Österreichsor or translated as the Freedom Party of Austria (FPO), holds a considerable number of seats within the Austrian Parliament. Migration has been a very important issue for Austria since the 1990s, and recently their stance towards migration can be seen when Austria decided to close its borders and refused to open its doors for migrants. In France, the National Front or now known as National Rallycame first at the national election. National Rally (NR) is an AntiImmigrant Party that refused migration activities around France (Alduy, 2014). One of the NR goals is to prove that it is possible to say 'no more to being submerged by the migrants. On July 2018, many of youth people attended anti-immigration protest that organized by Generation Nation and Youth League which is the far-right youth groups of France's National Rally. In Italy, Lega Nord also gained a lot of people that support Anti-Immigrant policy. Led by Matteo Salvini, the former Minister of Interior and Deputy Prime Minister, he is ultra anti-immigrant movement (Roberts, 2019). Salvini said that illegal migrants that live in Italy should leave. He added that under his ministry, no people smuggler would be allowed to dock in Italian ports (Roberts, 2019). Under Salvini's policies, Italy had been clearly against immigrants' movement who potentially entered Italy. Salvini used his role in the government to 
promote his party's aggressive stance against the EU (McKenna, 2019).

The main reason for the considerable increase in social support for parties with Anti-EU, Anti-Immigrants, or Eurosceptic tendencies is the inconsistency of the European Union regarding the issue. It is common to occur when a national or social security issue is involved. The reintroduction of internal border controls within the Schengen Zone magnifies the problem significantly, as it directly impacts the lives of the citizens of the European Union. The European Union member countries are getting tired of it and turned towards parties that are bold enough to hold their ground against migration.

The way individual countries within the European Union and the Schengen Area try to deal or mitigate the damage of the 2015 Migrant Crisis seems to be uncoordinated and disproportionate. From the prolonged reintroduction of internal border checks to the "all refugees are welcome" statement, the decision reflected that. Each country seems only to try to save itself while disregarding the future of the European Union and how their decision would affect their fellow nations. The first thing that the European Union could do is to double-down on countries that have violated the maximum time on the reintroduction of internal border checks within the Schengen Area in Germany, Austria, Norway, Sweden, Denmark, and France. The European Union should disallow any further extension and look for a compromise to preserve the integrity of the Schengen Area.

The European Union signed a deal with Turkey regarding the handling of migrants back in March 2016. In the Agreement, the European Union agreed to fund Humanitarian and Development projects for the migrants in Turkey. The European Union's budget for the deal was $€ 6$ billion, €3 billion within 2016-2017, and another €3 billion in 2017 - 2018 (European Council, 2019). In cooperation with the United Nations, Turkey allocated a fraction of the funding to establish a mandatory registration system for migrants who seek asylum within the country (Sahin, 2017). This mandatory system is handled by the Turkish Directorate General of Migration Management (DGMM). Migrants must submit identification information and important documents to the Provincial Directorate of Migration Management (PDMM). In return, registered migrants will be given protection, access to public services, and assistance from the government (UNHCR, n.d.). The European Union should follow this example and establish its registration system for migrants as well. A registration system for migrants in the European Union would benefit both the migrants and the European Union itself. For the supranational organization, verification of migrants would minimize the risk of undesirable individuals gaining entry into the European Union. It would also help European Union countries to track the movement of migrants within the Area by sharing the registration data, and it would also render official reallocation of migrants within the European Union possible. The European Union could use Frontex to help establish the registration system, as Frontex already has the political support of the supranational organization.

The integrity of the European Union is on the line. The time for inconsistencies and self-interests is over, and it is time to look forward in unison. People are noticing how disharmonious and disproportionate the European Union can be in tackling a major issue. Distrusts and dissatisfaction grows while each member states are fighting to secure their interests and disregarding others. The European Union and every member country have to regain the people's trust by bringing harmony and tackling the migrant issue with a common strategy. The European Union has to stop the internal border controls inside the 
Schengen Area and put a system that would simply make internal border controls unnecessary.

In addition to using Frontex as a physical and united front to strengthen border security in the Schengen area, programs similar to what Turkey's government is working on are active in the EU, namely Visa Information System (VIS), Schengen Information System (SIS), European Travel Information and Authorization System (ETIAS). VIS and SIS act as a digital information-sharing platform for Schengen states and Europe in general, while ETIAS works as the final digital line of defense. At the time of writing, both SIS and ETIAS are still on their way to being fully integrated by the Schengen states and EU in general. For SIS, this integration will include an expansion of the data gathered and shared to increase security. These new digital systems were put in place to tackle the secondary movement of immigrants, which is one of the main points of the internal border crisis. The data gathered and shared will allow law enforcers to coordinate and act accordingly.

To explain how they work briefly, SIS is an information system that gathers data on all EU citizens and third-country nationals and shares it with all participating countries to explain how they work briefly. This includes migrants and refugees. SIS also contains a system that can give law enforcement and border guards instructions to arrest a criminal or locate a missing object or person(s); VIS works in a similar vein with SIS; it gathers and shares data from and to the participating countries. The difference between the two is that VIS is applied to third-country nationals that have to provide Visa when they enter the Schengen area. This system tracks all external border crossing points and connects consulates in non-EU countries as well. ETIAS is very similar to VIS, the main difference being the subject of the system. While VIS applies to visa- required third-country nationals, ETIAS applies to visa-exempt third-country residents. In sum, all of them utilize the synchronization of data among Schengen countries in the European Union and enable it to be constantly updated, shared, and monitored so that every country in Schengen Area knows about the status of immigrants who pass the border and into the European Union.

Konig's article delves deep into the social effect of classification that comes with shared monitoring and tracking of immigrants and refugees between Schengen states and law enforcement. These negative impacts are mainly discriminatory treatments that may happen to suspected individuals. That, in short, is the negative impact these new technologies may bring. On the other hand, these new systems answer the problem that the EU is facing, that is, the major conflict of interest between Schengen states that ultimately ends in the reintroduction of physical internal border controls within the Area. These new digital systems provide an instrument Schengen state could use to coordinate to tackle the secondary movement issue effectively. We believe that weighing both the practical benefit and negative impact of such systems will give a real solution for the present problem faced.

It is essential to note that the Schengen Area is one of the most crucial parts of the EU's identity since it provides and facilitates free movement of people within member countries, which has reflected the EU's success in bringing the concept of regionalism itself. Aside from that, the Schengen Area has also undeniably contributed to boosting the economy and socio-culture performance of the region. The European countries, especially the EU members committed to Schengen, therefore are required to act quickly on countering the internal border controls problem. Because if said members just let the issue of inner border controls unsolved, it would eventually damage the existence of 
the Schengen Area, which has been remarkably become one of the essential traits that the union has.

The ship, which in this case is the Schengen Area, is sinking, and everybody has to do their part to save it instead of saving their own lives, or they might eventually jump out of the ship. Some alternatives or initiatives should be made to reach a resolution that could accommodate each country's interest and also the mutual interest of all members as a community. However, it does indeed require cooperation from all members within the union to formulate the needed initiatives for the ongoing issue. Since the members had already committed to the regional integration, they should be aware that every regional issue, especially a very fundamental one that relates to national and social security, should be taken and coordinated properly as well not just individually but also as a team, as a union.

\section{CONCLUSION}

The European Union (EU) faced a migrant crisis in 2015, dealing with a large influx of refugees due to the conflict in Syria. The purpose of the reintroduction is to screen and prevent undesirable individuals from entering their borders. Some of those countries cited the rise of terrorism and secondary movements as their reason to reintroduce internal borders controls. However, the reintroduction of the internal border controls by members of the European Union has created another issue that threatens the existence of the Schengen Area. Hence, some initiatives or alternatives are being made to overcome the rising problem. A wide range of technological applications is the reimplementation of border controls is a reasonable step taken by a country. To continue and tighten the rate of migrants entering the EU territory, there are various improvements and improvisation in implementing border controls. There are several steps taken by the EU for border control checks by utilizing technology (especially in data synchronizing and monitoring as mentioned in the discussion) such as Visa Information System (VIS), Schengen Information System (SIS), European Travel Information and Authorization System (ETIAS), and FRONTEX. Some of those programs will reduce the rate of migration to the European region because of the authorityin the system being implemented. Data obtained from several systems above are also considered to facilitate border control checks in their implementation. While the new technology carries social risk such as discrimination towards refugees and immigrants, we believe that with sufficient monitoring, cooperation, and integration from the Schengen states, the new programs will prove to be very useful to tackle the security concerns and conflicting interests within the Schengen area and remove the needs of unnecessarily long physical internal border controls.

\section{BIBLIOGRAPHY}

Aisch, G., \& Pearce, A. (2016). Rosseau Bryant. How Far Is Europe Swinging to the Right? Retrieved from New York Times: https://www.nytimes.com/interactive/2016 /05/22/world/europe/europe-right-wingaustria-hungary.html

Alduy, C. (2014). How a Far-Right, Anti-Immigrant Party Became France's 'New Normal. Retrieved from The Nation: https://www.thenation.com/article/howfar-right-anti-immigrant-party-becamefrances-new-normal /

Anne, N. (2016). Merkel, Germany and Europe's Migrant Crisis - Analyzing Domestic International Synergies in Chancellor Merkel's. Retrieved from International Studies Association: http://web.isanet.org/Web/Conferences/CE EISA-ISA-LBJ2016/Archive/4f068142-b4114eb0-87f9-e2f644b8a9d4.pdf

BBC. (2016). Migrants Crisis: Austria Sets Asylum Claims Cap and Transit Limit. Retrieved from BBC: https://www.bbc.com/news/worldeurope-35600220

CBC Radio. (2015). Croatia Flooded With Refugees, Critics Says EU Failing Them. Retrieved from CBC

Radio: 
https://www.cbc.ca/radio/thecurrent/thecurrent-for-september-21-2015-

1.3236514 /croatia-flooded-with-refugeescritics-say-eu-failing-them-1.3236549

Deustche Welle. (2019). Orban: Refugee Crisis is a 'German Problem'. Retrieved from DW: https://www.dw.com/en/orban-refugeecrisis-is-a-german-problem/a-18691306

DW. (2019, August 5). EU Border Force Frontex Implicated in Migrants Abuse. Retrieved from DW: https://www.dw.com/en/eu-borderforce-frontex-implicated-in-migrantabuse/a-49892097

Economist, T. (2018). Border Checks Are Undermining Schengen. Retrieved November 25, 2019, from https://www.economist.com/europe/2018/ $10 / 27$ /border-checks-are-underminingschengen

Ensor, J. (2016). Photo of My Dead Son Has Changed Nothing 'Says Father of Drowned Syrian Refugee Boy Alan Kurdi. Retrieved from Telegraph:

https://www.telegraph.co.uk/news /2016/0 9/01/photo-of-my-dead-son-has-changednothing-says-father-of-drowned/

Euractiv. (2017). Polish PM Rejects EU 'Blackmail' on Migrants. Retrieved from Euractiv: https://www.euractiv.com/section/justicehome-affairs/news/polish-pm-rejects-eublackmail-on-migrant-quotas/

EUR-Lex. (2019). Union Code on The Rules Governing the Movement Persons Across Borders (Schengen Borders Code). Retrieved from $\quad$ EUR-Lex: https://eurlex.europa.eu/legalcontent/EN/TXT/PDF/?uri=CELEX:32016R0 399\&from $=\mathrm{EN}$

European Commission. (2019). EU Delivers on Strangers European Border and Coast Guard to Support Member States. Retrieved from European Commission: https://ec.europa.eu/commission/presscorn er/detail/en/statement_19_6237

European Council. (2019). EU Facility For Refugees in Turkey, List Project Committed/Decided, Contracted, Disbursed. Retrieved from European Council: https://ec.europa.eu/neighbourhoodenlargement/sites/near/files/facility_table.p df

European Council. (n.d.). Schengen Agreement Convention. Retrieved from European Council: https://ec.europa.eu/homeaffairs/e-library/glossary/schengenagreement-convention_en

European Parliament. (2017). Secondary Movements of Asylum-seekers in the EU Asylum System. Retrieved from European
Union:

http://www.europarl.europa.eu/RegData/et udes/BRIE/2017/608728/EPRS_BRI(2017) 608728_EN.pdf.

European Parliament. (2018). The function of Schengen Area. Retrieved from European Parliament:

https://www.europarl.europa.eu/doceo/doc ument/A-8-2018-0160_EN.html

Hayes, B. (2004). The proposals explained from the Schengen Information System to SIS II and the Visa Information (VIS). Statewatch Analysis.

Kamasa, J. (2019). New Technologies for Border Controls in Europe. CSS Analyses in Security Policy No. 255. Retrieved from CSS Eth Zurich: https://css.ethz.ch/content/dam/ethz/speci al-interest/gess/cis/center-for-securitiesstudies/pdfs/CSSAnalyse255-EN.pdf

Konig, M. (2016). The Borders, They Are a Changing! The Emergence of Socio-Digital Borders in the EU. Internet Policy Review, Journal on Internet Regulation Volume 5, Issues 1. Retreived from Maastricht University: https://openjournals.maastrichtuniversity.n l/Marble/article/view/268/225

Lichfield, J. (2015). Germany Opens Its Gates: Berlin says all Syrian asylum-seekers are welcome to remain, as Britain is urged to make a 'similar statement'. Retrieved from Independent:

https://www.independent.co.uk/news/worl d/europe/germany-opens-its-gates-berlinsays-all-syrian-asylum

McKenna, J. (2019). Matteo Salvini Join Protest Against Italy's New Government As It Moves To Undo Hardline Policies. Retrieved from Telegraph: https://www.tel egraph.co.uk/news /2019/0 9/08/matteo-salvini-join-protest-againstitalys-new-government-moves /

Roberts, H. (2019). European Election: Salvini Becomes Prime Minister in All But Name After Italian Far-Right Party Wins Big. Retrieved from The Independent: https://www.independent.co.uk/news/worl d/europe/european-elections-italy-matteosalvini-league-liga-five-star-co alit

Sahin, T. (2017). How Does The Registration System Work For Refugees in Turkey? Retrieved from TRT World: https://www.trtworld.com/turkey/howdoes-the-registration-system-work-forrefugees-in-turkey--12264.

Scatch, K. (2019). Border Checks in EU Countries Challenge Schengen Agreements. Retrieved from DW: https://www.dw.com/en/border- 
JPPUMA: Jurnal Ilmu Pemerintahan dan Sosial Politik UMA (Journal of Governance and Political Social UMA), (9)(2)(2021):173-183

checks-in-eu-countries-challenge-schengenagreement/a-51033603

Schumacher, E. (2018). What is the Frontex European Border and Coast Guard Agency. Retrieved from

DW:

https://www.dw.com/en/what-is-thefrontex-the-european-border-and-coastguard-agency/a-44441231.

The Economist. (2018). Border Checks Are Undermining Schengen. Retrieved from The Economist:

https://www.economist.com/europe/2018/ $10 / 27$ /border-checks-are-underminingschengen

The Guardian. (2015). Angela Merkel Defends Germany Handling of Refugee Influx. Retrieved from The Guardian: https://www.theguardian.com/world/2015 /sep/15/angela-merkel-defends-germanyshandling-of-refugee-influx
The Japan Times. (2019). EU Border Force Frontex Accused of Allowing Abuse of Migrants. Retrieved from The Japan Times: https://www.japantimes.co.jp/news/2019/ 08/06/world/social-issues-world/euborder-force-frontex-accused-allowingabuse-migrants /

UNHCR. (n.d.). Registration with The Turkish Authorities. Retrieved from UNHCR: https://help.unhcr.org/turkey/informationfor-syrians/reception-and-registration-withthe-turkish-autho rities /

Vladisavljevic, A. (2019). Migrants Still Trekking Into Croatia Despite Winter Cold. Retrieved from Balkan Insight: https://balkaninsight.com/2019/01/18/col d-winter-not-stopping-the-migrants-ontheir-way-01-16-2019/ 